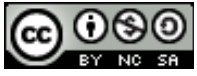

https://doi.org/10.31743/abmk.12327

KS. WALDEMAR WITOLD ŻUREK SDB* - LUBLIN

\title{
SALEZJANIN, WYCHOWAWCA, ARTYSTA - ŻYCIE I DZIAŁALNOŚĆ KOADIUTORA JANA KAJZERA (1892-1976)
}

\begin{abstract}
Streszczenie
Artykuł przedstawia sylwetkę Jana Kajzera (1892-1976), salezjanina, wychowawcy i autora wielu projektów z zakresu sztuki użytkowej, wieloletniego nauczyciela i dyrektora szkoły zawodowej w Zakładzie Salezjańskim im. KsiędzaBoskowOświęcimiu.Kierowałtamtejsząplacówkądydaktycznąw trudnych latach. Szkolnictwo salezjańskie w Polsce osiągnęło największy rozwój w roku szkolnym 1947/48, po czym do 1963 r. następowała stopniowa likwidacja i upaństwowienie 20 szkół salezjańskich w kraju. Jan Kajzer był autorem wielu projektów mebli - głównie kościelnych, tkanin i prac malarskich, które zaskarbiły mu uznanie w środowisku sztuki. Prywatnie odznaczał się wielką pobożnością, kierując się wzorem założyciela ks. Jana Bosko. Artykuł niniejszy dowodzi, że koadiutor Jan Kajzer może być postrzegany jako wybitny przedstawiciel zgromadzenia salezjanów w Polsce, obok kard. Augusta Hlonda, abp. Antoniego Baraniaka czy koadiutorów: Klemensa Hlonda i Szymona Szmergalskiego.
\end{abstract}

Słowa kluczowe: Jan Kajzer; historia Zgromadzenia Salezjańskiego; salezjanie; Zakład Salezjański im. Księdza Bosko w Oświęcimiu; wychowanie salezjańskie

* Ks. Waldemar W. Żurek SDB - dr hab. historii Kościoła; profesor KUL w Ośrodku Archiwów, Bibliotek i Muzeów Kościelnych

e-mail: waldemar.zurek@kul.pl

https://orcid.org/0000-0002-5602-5077 


\section{Wprowadzenie}

W dniu 6 stycznia 1976 r. zmarł w Oświęcimiu salezjański brat zakonny (koadiutor) Jan Kajzer ${ }^{1}$. Liturgia pogrzebowa, która odprawiona została trzy dni później i której przewodniczył sufragan krakowski biskup Stanisław Smoleński, zgromadziła wielu księży, siostry zakonne, wychowanków Zakładu Salezjańskiego im. Księdza Bosko w Oświęcimiu oraz mieszkańców miasta, którzy stali w szpalerach wzdłuż ulic posuwającego się konduktu żałobnego. Wszyscy żegnali zmarłego salezjanina wielce zasłużonego dla zgromadzenia, Kościoła w Polsce, miasta i polskiej oświaty. Jan Kajzer przeżył 84 lata, z czego $62 \mathrm{w}$ zgromadzeniu salezjańskim, głównie w Oświęcimiu, wychowując i kształcąc w zawodzie polską młodzież. Sam otrzymał gruntowne wykształcenie zawodowe, był więc w zgromadzeniu w pewnym sensie 'uprzywilejowany' do wykonywania bardziej odpowiedzialnych prac i zajmowania urzędów, co nie było dostępne dla wszystkich koadiutorów. Był ponadto typem lojalisty i pacyfisty².

\section{Curiculum vitae}

Jan Kajzer urodził się 3 czerwca 1892 r. w Łodygowicach koło Bielska, w Galicji, w diecezji krakowskiej. Był synem Józefa i Barbary z domu Janota. Szkołę powszechną 7-klasową ukończył w 1905 r. w Oświęcimiu, po której jako trzynastoletni chłopiec podjął pracę fizyczną w charakterze pomocnika murarskiego ${ }^{3}$. Dnia 3 sierpnia 1908 r., w wieku 16 lat, został przyjęty do Zakładu Salezjańskiego św. Jana Bosko w Oświęcimiu i skierowany na naukę stolarstwa w miejscowej 4-letniej szkole rzemieślniczej. Po rozmowie kwalifikacyjnej decydującej o przyjęciu do zakładu i szkoły dyrekcja zakładu zwolniła Jana z opłat za internat i naukę w szkole. $Z$ pewnością zdecydowała o tym jego sytuacja rodzinna - był półsierotą, a w takich wypadkach dyrekcja zakładu przyznawała ulgi, a nawet zwolnienia ze świadczeń. Prawdopodobne jest, że przy przyjęciu do szkoły kandydat wykazał się inteligencją i odpowiednim zasobem wiedzy do nauki stolarstwa. Po ukończeniu szkoły rzemieślniczej złożył 25 czerwca 1912 r. egzamin czeladniczy, tzw. wyzwoliny. W tym też roku poprosił o przyjęcie do nowicjatu salezjańskiego, który odbył w latach 1913-1914 w Radnej w Słowenii, gdzie złożył pierwsze śluby zakonne 3 lipca 1914 r. Śluby wieczyste złożył 2 sierpnia 1917 r. $^{4}$

\footnotetext{
${ }^{1}$ Kaizer - spolszczonej wersji swojego nazwiska używał już w latach międzywojennych. A. Kostrzyńska-Miłosz, Koadiutor Jan Kajzer współtwórca polskiego stylu art deco, „Seminare”, 35 (2014) nr 1, s. 171.

${ }^{2}$ A. Świda, Jan Kajzer (1892-1976) wychowawca z powołania, w: Chrześcijanie, t. 12, red. B. Bejze, Warszawa 1984, s. 285-286.

${ }^{3}$ Trudno obecnie dociec, dlaczego szkołę podstawową kończył w oddalonym o 47 kilometrów od domu rodzinnego Oświęcimiu. Już wówczas był półsierotą po śmierci ojca. Może ktoś z rodziny przyjął do siebie Jana, by pomóc jego matce. P. Kowol, Działalność dydaktyczna i pedagogiczna Jana Kajzera (1892-1976), Lublin 1989, s. 15-16 [mps KUL].

${ }^{4}$ Archiwum Salezjańskiej Inspektorii Krakowskiej (dalej: ASIK), sygn. A 2029, Teczka personalna koad. Jana Kajzera, Życiorys Jana Kajzera (Oświęcim 20 stycznia 1951); Personel salezjański
} 
Po nowicjacie został skierowany do pracy w fabrykach i wytwórniach mebli w Wiedniu i Lublanie. Od 4 października 1915 r. kierował pracownią stolarską w Salezjańskiej Szkole Rzemieślniczej w Oświęcimiu oraz prowadził zajęcia z przedmiotów teoretycznych: technologii stolarskiej, rysunków zawodowych i matematyki - do wakacji $1921 \mathrm{r}$. W czasie I wojny światowej stawał 22 maja 1916 r. przed wojskową komisją poborową w Oświęcimiu i został powołany do służby ${ }^{5}$. W latach 1922-1929 ponownie podjął obowiązki kierownika stolarskiego działu kształcenia w szkole oświęcimskiej6.

Wybuch II wojny światowej zastał go w domu salezjańskim (zakładzie) Świętej Rodziny w Warszawie przy ulicy Lipowej 13. W pierwszej połowie września 1939 r. wraz z grupą salezjanów uciekał przed Niemcami na wschód kraju, docelowo do Reginowa7 . Po agresji 17 września 1939 r. Związku Radzieckiego na Polskę i okupacji wschodnich ziem Polski Kajzer osiadł w domu salezjańskim w Sokołowie Podlaskim. Na wiosnę 1940 r. udał się do zakładu w Kielcach. Tutaj uczył na tajnym kursie stolarskim grupe młodych salezjanów na przyszłych instruktorów stolarstwa i nauczycieli przedmiotów teoretycznych. Pomagał także koad. Piotrowi Chroboczkowi w pracy w tamtejszej stolarni ${ }^{8}$.

i wychowankowie Zakładu im. Księdza Bosko w Oświęcimiu 1898-1917, oprac. i wyd. W.W. Żurek, Lublin 2014, s. 103.

${ }^{5}$ Brak szczegółowych informacji, czy był reklamowany przez przełożonych prowincji na komisji wojskowej, czy też wyjechał na front i kiedy wrócił. W danych na temat kierowników pracowni rzemieślniczych w Oświęcimiu z lat wojny nie ma na ten temat żadnej wzmianki. Ksiądz Zygmunt Kuzak we wspomnieniu pośmiertnym o Janie Kajzerze mówi jedynie o jego stawieniu się na komisji wojskowej. ASIK, Zespół: Listy pośmiertne współbraci, T. III: K - Ł, Z. Kuzak, Wspomnienie pośmiertne o śp. koad. Janie Kajzerze, s. 4 (dalej: Kuzak, Wspomnienie pośmiertne).

${ }^{6}$ W.W. Żurek, Szkoły salezjańskie w Oświęcimiu na tle salezjańskiego szkolnictwa średniego ogólnokształcacego i zawodowego na ziemiach polskich, Lublin 2010, s. 487-490.

${ }^{7}$ Reginów - placówka salezjańska najbardziej wysunięta na wschodnich Kresach II Rzeczypospolitej, uważana była za najbezpieczniejszą do schronienia się przed niemieckim najeźdźcą. Właściciel majątku Reginów hrabia Jan Jundził-Baliński (1899-1974) część swego majątku (drewniany pałac, budynki gospodarcze, grunty orne i łąki) przekazał w 1934 r. salezjanom na cele oświatowo -wychowawcze. Ich obecność w tej kresowej miejscowości rozpoczęła się wiosną 1935 r. Salezjanie zorganizowali tam męskie schronisko z możliwością dokształcania zawodowego. Ponadto przejęli oni duszpasterstwo w drewnianej filialneej kaplicy Najświętszej Maryi Panny z 1827 r., oddalonej o 22 kilometry od kościoła parafialnego w Nowopolnej, w dekanacie Słomin w archidiecezji wileńskiej. Po erygowaniu domu zakonnego otwarto w roku szkolnym 1937/38 w Reginowie pierwszą klasę gimnazjalną Małego Seminarium Duchownego o profilu misyjnym. Rozpoczęło w nim naukę 60 uczniów z całej Polski. W drugim roku szkolnym seminarium kształciło w czterech klasach 130 uczniów. Rozwój tej placówki przekreślił wybuch II wojny światowej. We wrześniowym eksodusie Polaków na wschód żaden z salezjanów nie dotarł do Reginowa. J. Niewęgłowski, Wychowawczo -społeczna działalność salezjanów w Polsce w latach 1898-1989, Warszawa 2011, s. 315-316; A. Świda, Salezjańskie szkolnictwo w Polsce (zarys), w: 75 lat działalności salezjanów w Polsce, red. R. Popowski, S. Wilk, M. Lewko, Łódź-Kraków 1974, s. 52.

${ }^{8}$ W Kielcach przy parafii Świętego Krzyża salezjanie prowadzili w tamtejszym zakładzie rzemieślniczą szkołę z działem krawieckim i stolarskim. Po wkroczeniu do miasta 4 września 1939 r. Niemców budynki zakładowe (pracownie stolarska i krawiecka, sala oratorium młodzieżowego) zostały przez nich zajęte, a częściowo stały nieużyteczne. Za pozwoleniem niemieckich władz oku- 
W 1943 r. przebywał poza zgromadzeniem w parafii w Hołubli w powiecie siedleckim. Zaprojektował polichromię i całościowe wyposażenie tamtejszego kościoła parafialnego. Zanim ukończył te prace, proboszcz parafii w Hołubli zaproponował Kazjerowi wykonanie wyposażenia dla sześciu kościołów w okolicy. Jednak jeszcze w tym roku inspektor Prowincji św. Jacka w Krakowie ks. Jan Ślósarczyk skierował koad. Kazjera do pracy w sierocińcu prowadzonym przez salezjanów w Prusach koło Krakowa. Obiekty te, którymi zarządzali wówczas Niemcy, salezjanie przejęli w administrację w czerwcu 1942 r. Okupanci powierzyli prowadzenie schroniska osobom świeckim, a zakonnikom pozostawili posługę pastoralną wychowanków. Salezjanie planowali zorganizowanie tam pracowni stolarskiej dla praktycznej nauki zawodu' ${ }^{9}$. W Prusach koad. Kajzer pełnił obowiązki instruktora stolarskiego i nauczyciela przedmiotów teoretycznych dla dwudziestu wychowanków. Pod koniec lipca 1945 r. po zlikwidowaniu w Prusach kursu zawodu stolarskiego wyposażenie warsztatów i narzędzia zostały przewiezione do zakładu oświęcimskiego, gdzie przyjęto także 15 uczniów sierot z Prus. Wraz z nimi przybył koad. Kajzer, który organizował w Oświęcimiu od podstaw szkołę zawodową. Dzięki maszynom stolarskim przywiezionym z Prus można było w roku szkolnym 1945/46 po 6-letniej przerwie prowadzić w Oświęcimiu kształcenie zawodowe stolarzy (park maszynowy zakładu salezjańskiego został wywieziony przez Niemców do obozu koncentracyjnego Auschwitz ${ }^{10}$ ).

Oprócz szkoły zawodowej w Zakładzie Księdza Bosko koad. Kajzer na wniosek Kuratorium Okręgu Szkolnego w Krakowie zorganizował w Oświęcimiu w roku szkolnym 1945/46 Gimnazjum Mechaniczne z 44 uczniami i Gimnazjum

pacyjnych koad. Chroboczek prowadził w zakładzie kieleckim stolarnię pod własnym szyldem, wykonując usługi dla wojska niemieckiego i Czerwonego Krzyża, potem także dla mieszkańców miasta. ASIK, sygn. A 2029, Teczka personalna koad. Jana Kajzera, J. Kajzer, Moje przeżycia od 1 IX 1939 roku, s. 2-3; Świda, Jan Kajzer (1892-1976) wychowawca z powołania, s. 266.

${ }^{9}$ Tamtejszy Zakład Fundacji im. Piotra Michałowicza posiadał piętrowy budynek dla 70 chłopców, ogród, gospodarstwo rolne o powierzchni 115 ha, młyn i płatkarnię produkującą dla Niemców. Od lipca 1942 r. zakładem zarządzali Niemcy. Zarząd niemiecki zamienił dotychczasowy sierociniec w dom poprawczy dla młodych przestępców. Wycofujący się w 1945 r. Niemcy stacjonujący w zakładzie planowali zniszczyć magazyny żywnościowe, młyn i obiekty wojskowe. Dzięki zabiegom koad. Kajzera niemiecki komendant nie wykonał rozkazu. Zanim sowiecka armia wkroczyła do Prus, magazyn żywnościowy obrabowali okoliczni mieszkańcy i wychowankowie domu poprawczego. Kuzak, Wspomnienie pośmiertne, s. 4; J. Pietrzykowski, Towarzystwo Salezjańskie w Polsce w warunkach okupacji 1939-1945, Warszawa 2015, s. 111-113; tenże, Salezjanie w Polsce 1945-1989, Warszawa 2007, s. 35.

${ }^{10}$ Wszystkie maszyny, urządzenia, środki transportu i materiały z magazynów szkolnych zarekwirowali Niemcy i wywieźli z zakładu. Pomieszczenia pracowni zawodowych zostały przez nich przebudowane dla potrzeb wojennych. Skrzydło zachodnie zakładu, część skrzydła głównego, jadalnia chłopców i przełożonych, kuchnia i piekarnia zostały 13 września 1944 r. zbombardowane w czasie nalotów amerykańskich samolotów. Ze zrabowanych urządzeń szkolnych udało się drogą sądową (8 listopada 1945) odzyskać tylko jedną maszynę - strugarkę do metalu z pracowni ślusarskiej oraz jeden silnik elektryczny. Niewęgłowski, Wychowawczo-społeczna działalność salezjanów w Polsce, s. 561-563; Salezjańskie szkoły rzemieślnicze w Oświęcimiu 1914-1971. Kronika, oprac. i wyd. W.W. Żurek, Lublin 2018, s. 113-114; relacja ks. Stanisława Urbańczyka, 4 sierpnia 2018, Oświęcim (zbiory własne autora). 
Stolarskie z 6 uczniami ${ }^{11}$. Na życzenie Ministerstwa Odbudowy koad. Kajzer został dyrektorem zorganizowanej od 1 lipca 1947 r. 2-letniej Średniej Szkoły Rzemiosł Budowlanych dla dorosłych. Wymienione trzy szkoły zawodowe mieściły się w przydzielonych salezjanom przez Ministerstwo Odbudowy poesesmańskich blokach w Oświęcimiu na Zasolu. Przez trzy lata Jan Kajzer prowadził kursy wieczorowe dla rzemieślników budowlanych i ślusarzy maszynowych - do chwili likwidacji szkół w 1951 r. ${ }^{12}$

Dnia 1 sierpnia 1945 roku Jan Kajzer objął stanowisko starszego asystenta w Katedrze Architektury Wnętrz Akademii Sztuk Pięknych w Warszawie. Jednak z powodu odległości i obowiązków dyrektorskich w Oświęcimiu zrezygnował w marcu $1946 \mathrm{r}$. z pracy na ASP. W Oświęcimiu pozostał dyrektorem szkoły zawodowej w zakładzie do końca lipca 1971 r. Przekazał to stanowisko dotychczasowemu zastępcy - ks. Stanisławowi Urbańczykowi ${ }^{13}$.

Warunki mieszkaniowe Jana Kajzera w zakładzie oświęcimskim były skromne, choć porównywalne z pozostałymi pracującymi tam salezjanami. Dysponował jednym pokojem, który był jego warsztatem pracy, miejscem przyjmowania interesantów i znajomych oraz był jego sypialnią. Nawet w późnym wieku obywał się bez pomocy drugich ${ }^{14}$.

\section{Podnoszenie kwalifikacji zawodowych}

Jan Kajzer był rozmiłowany w zawodzie stolarskim. Miał w pamięci słowa ks. Jana Bosko, który chciał widzieć koadiutorów na każdym miejscu: wykonujących domowe zajęcia, pracujących w biurach i w warsztatach zawodowych, jako instruktorzy i nauczyciele, majstrowie i na stanowiskach kierowniczych w szkołach zawodowych. Stopniowo zdobywał Kajzer kwalifikacje zawodowe - od czeladnika po nauczyciela teoretycznego i praktycznego zawodu, aż do uzyskania kwalifikacji do kierowania placówką dydaktyczną. W codziennym życiu zawodowym był dydaktykiem, wychowawcą, artystą projektantem i dyrektorem szkoły. Dał się poznać jako pedagog i wychowawca młodych w stylu salezjańskiego systemu wychowawczego ks. Jana Bosko, zwanego systemem prewencyjnym, opartym na rozumie, religii i miłości ${ }^{15}$.

Naukę stolarstwa rozpoczął w Salezjańskiej Szkole Rzemiosł w Oświęcimiu, którą ukończył z dyplomem czeladnika. Po nowicjacie skierowany został do pracy w zagranicznych fabrykach mebli. Zdobyta tam wiedza i doświadczenie zawodowe stopniowo przygotowało go do sprawowania funkcji kierownika szkolnej pracowni stolarskiej w Oświęcimiu w latach 1915-1921 i 1922-192916.

Stolarskie umiejętności poszerzał Jan Kajzer m.in. na kursie rysunków zawodowych dla stolarzy urządzonym przez Miejskie Muzeum Przemysłowe im. dra

${ }^{11}$ Salezjańskie szkoty rzemieślnicze w Oświęcimiu, s. 112.

${ }^{12}$ Kuzak, Wspomnienie pośmiertne, s. 4; W. Żurek, Salezjańskie szkolnictwo ponadpodstawowe w Polsce 1900-1963. Rozwój i organizacja, Lublin 1996, s. 331.

${ }^{13}$ Kostrzyńska-Miłosz, Koadiutor Jan Kajzer wspóttwórca polskiego stylu, s. 174.

${ }^{14}$ Kuzak, Wspomnienie pośmiertne, s. 6.

${ }^{15} \mathrm{P}$. Braido, Prevenire non reprimere. Il sistema educativo di don Bosco, Roma 1999.

${ }^{16}$ Kostrzyńska-Miłosz, Koadiutor Jan Kajzer wspóttwórca polskiego stylu, s. 172. 
Adriana Baranieckiego w Krakowie od 15 października 1920 do 30 maja 1921 r. ${ }^{17}$ Po sześcioletnim prowadzeniu szkolnej stolarni w Oświęcimiu (1915-1921) skierowany został na rok 1921/22 do Szkoły Architektury Wnętrz w Norymberdze. Przebywając w Niemczech, zapisał się na wieczorowy kurs księgowości i korespondencji, a po powrocie do kraju uzupełniał umiejętności stolarskie w Szkole Przemysłu Artystycznego w Krakowie w latach 1924-1926. W nagrodę za wykonaną pracę wydelegowany został w $1925 \mathrm{r}$. przez dyrekcję tej szkoły na światową wystawę do Paryża ${ }^{18}$. Rezygnując z wypoczynku, wakacje 1926 r. spędził jako uczestnik kursu barwnictwa drzewnego i politury w Technische und Kunstgewerbliche Tischler Fachschule w Cöthen (Anhalt) w Niemczech ${ }^{19}$. Zdobytą na kursach wiedzę teoretyczną i praktyczną przekazywał nauczycielom i kierownikom zawodu stolarskiego na kursie zorganizowanym od 4 do 30 lipca 1927 r. przez Ministerstwo Wyznań Religijnych i Oświecenia Publicznego w Warszawie ${ }^{20}$.

Najprawdopodobniej współpraca z Ministerstwem zainspirowała koad. Kajzera do podjęcia studiów na Wydziale Architektury Wnętrz w Warszawskiej Szkole Sztuk Pięknych, przemianowanej w 1932 r. na Akademię Sztuk Pięknych. Na tej uczelni już w 1927 r. był wykładowcą na kursach dla nauczycieli zawodu stolarskiego organizowanych przez Ministerstwo Wyznań Religijnych i Oświecenia Publicznego. Od 1 lipca 1929 r. Jan Kajzer współpracował ze Szkołą Sztuk Pięknych jako kierownik działu drzewnego, czyli instruktor stolarski. Na Wydziale Architektury Wnętrz prowadził także zajęcia teoretyczne z przedmiotów zawodowych (technologii i kompozycji wnętrz i sprzętów) dla czeladników i mistrzów cechu stolarskiego Warszawy. Otrzymywane wyróżnienia na konkursach szkolnych sprawiły, że postrzegano tego salezjanina jako dobrego artystę, a władze uczelni doceniając jego dorobek, zaproponowały mu stanowisko asystenta w Katedrze Architektury Wnętrz ${ }^{21}$.

Na Akademii Sztuk Pięknych Kajzer studiował wiele dziedzin. Rozpoczął od wpisu na listę uczelni 6 maja 1930 r. do pracowni malarskiej Tadeusza Pruszkowskiego (1888-1942)22. Jednak już jesienią tego roku studiował projektowanie u prof. Józefa Czajkowskiego ${ }^{23}$, meble w latach 1933-1937 u prof. Wojciecha Ja-

${ }^{17}$ ASIK, sygn. A 2029, Teczka personalna koad. Jana Kajzera, Odpis wierzytelny świadectwa z 30 V 1921 roku, L. 211/9/21.

${ }^{18}$ Exposition Internationale des Arts Décoratifs et Industriels Modernes w Paryżu 1925 roku. Chodzi o cykliczne wystawy światowe prezentujące dorobek kulturalny, naukowy i techniczny krajów świata, na których organizatorzy mieli możliwość reklamy swego dorobku i stwarzali korzystne warunki do konkurencji, m.in. w dziedzinie rozwiązań technicznych i architektonicznych. Świda, Jan Kajzer (1892-1976) wychowawca z powołania, s. 266.

${ }^{19}$ Kostrzyńska-Miłosz, Koadiutor Jan Kajzer wspóttwórca polskiego stylu, s. 172.

${ }^{20}$ Kowol, Działalność dydaktyczna i pedagogiczna Jana Kajzera, s. 27.

${ }^{21}$ Kostrzyńska-Miłosz, Koadiutor Jan Kajzer wspóttwórca polskiego stylu, s. 172-173; Kowol, Działalność dydaktyczna i pedagogiczna Jana Kajzera, s. 28-29.

${ }^{22}$ Podaną w życiorysie informację, że na studia zapisał się w 1929 r., należy rozumieć tak, że początkowo był wolnym słuchaczem. ASIK, sygn. A 2029, Teczka personalna koad. Jana Kajzera, Życiorys Jana Kajzera z 18 XI 1949 roku.

${ }^{23}$ Józef Czajkowski (1872-1947) - polski malarz, architekt, grafik, pedagog. Urodził się w Warszawie. Studiował w Monachium, Wiedniu, Paryżu i w Krakowie. Tworzył w stylu secesji, malując pejzaże, portrety i sceny rodzajowe. Był wykładowcą w krakowskiej ASP, na Wydziale Sztuk Pięk- 
strzębowskiego ${ }^{24}$, tkactwo klinowe u Heleny Bukowskiej, żakard ${ }^{25} \mathrm{u}$ Lucjana Kintopfa $^{26}$, ceramikę u Karola Józefa Tichego ${ }^{27}$ i rzeźbę u Tadeusza Breyera ${ }^{28}$. Profe-

nych Uniwersytetu Stefana Batorego w Wilnie i w warszawskiej ASP. Jest autorem projektów mebli, witraży, plakatów, kilimów i okładek książek. W twórczości nawiązywał do polskiej sztuki ludowej. Zmarł w Warszawie. G. Janneau, Encyklopedia sztuki dekoracyjnej, Warszawa 1978, s. 70.

${ }^{24}$ Wojciech Jastrzębowski (1884-1963) - artysta projektujący sztukę użytkową i grafikę w stylu secesji. Urodził się w Warszawie. Od 1904 r. studiował w krakowskiej ASP i był uczniem Józefa Mehoffera, następnie w Paryżu. Po powrocie w 1911 r. był współzałożycielem stowarzyszenia nazywanego od 1913 r. Warsztaty Krakowskie, które zajmowały się projektowaniem i wykonywaniem wzornictwa przemysłowego. Od 1912 r. był wykładowcą na kursach dla rzemieślników organizowanych w Muzeum Techniczno-Przemysłowym w Krakowie. W grudniu 1921 r. przeprowadził się do Warszawy. W roku następnym rozpoczął nauczanie w Szkole Sztuk Pięknych. W 1926 r. był współorganizatorem Spółdzielni Artystów Plastyków „Ład”. W 1935 r. został prorektorem Akademii Sztuk Pięknych, a od 1936 r. rektorem tej uczelni. W 1939 r. znalazł się w Londynie. Do kraju powrócił w 1947 r. i rozpoczął współpracę z późniejszym Instytutem Wzornictwa Przemysłowego. Był uzdolnionym plastykiem projektującym obrazy, plakaty, afisze, polichromie, kilimy, medale, wnętrza, pomniki, witraże, meble, monety i znaczki pocztowe. Wielkim jego sukcesem była paryska wystawa światowa w 1925 r. Zaprojektował wnętrze Ministerstwa WRiOP (1924) oraz wnętrze statków m/s Piłsudski i m/s Batory (1934-1936). Jastrzębowski Wojciech, w: Nowa encyklopedia powszechna PWN, tom 3: I- , Warszawa 1995, s. 154.

${ }^{25}$ Żakard - maszyna włókiennicza do produkcji dzianin zaopatrzona w urządzenie o tej nazwie sterujące grupami nitek osnowowych na krośnie, służące do otrzymywania na tkaninie różnych wzorów.

${ }^{26}$ Lucjan Kintopf (1898-1979) - mistrz żakardu. Z techniki żakardowej uczynił instrument twórczej kreacji. Przemysłowe narzędzie produkcji tekstylnej przekształcił w nośnik artystycznej wypowiedzi. Lniane i jedwabne autorskie tkaniny żakardowe stały się wizytówką Spółdzielni Artystów Plastyków „Ład”, założonej w Warszawie w 1926 r. Kintopf był jej współzałożycielem i pierwszym dyrektorem. Tkaniny Spółdzielni „Ład” łączyły nowoczesność z polską tradycją i dekorowały nowo powstające gmachy urzędów państwowych, budynki użyteczności publicznej oraz mieszkania prywatne w stolicy. Były stałym elementem ekspozycji prezentowanych na blisko 100 wystawach sztuki polskiej w kraju i za granicą (Liège, Kopenhaga, Berlin, Moskwa, Nowy Jork, Kanada), nagradzane na prestiżowych wystawach światowych. W Państwowej Wyższej Szkole Sztuk Plastycznych w Łodzi pojawił się w 1950 r. Tam okazał się wszechstronnie wykształcony, łączący uzdolnienia plastyczne z technicznymi, był świetnym pedagogiem, niepodważalnym autorytetem i mistrzem. W szkole łódzkiej prowadził warsztaty tkackie i utworzył pierwszą Pracownię Projektowania Tkanin Żakardowych, dbając o łączenie umiejętności technicznych z pracą czysto projektową. Wykształcił wielu twórców sztuki żakardowej. Kintopf realizowali się również we współczesnej przygodzie artystycznej, nazywanej dzisiaj ,polską szkołą tkaniny”. Kintopf Lucjan, w: Nowa encyklopedia powszechna PWN, tom 3: I- , Warszawa 1995, s. 356.

${ }^{27}$ Karol Józef Tichy (1871-1939) - malarz i artysta. Zajmował się również ceramiką artystyczną, projektowaniem mebli, tworzył witraże w stylu secesji. Studiował prawo na Uniwersytecie Jagiellońskim, a malarstwo w Szkole Sztuk Pięknych w Krakowie. Edukację kontynuował w Monachium oraz w Paryżu. Był członkiem założycielem Spółdzielni Artystów Plastyków „Ład”. Zmarł w Warszawie. Został pochowany na cmentarzu w Niepołomicach. Tichy Karol Józef, w: Wielka encyklopedia powszechna PWN, tom 11, Warszawa 1968, s. 524.

${ }^{28}$ Tadeusz Breyer (1874-1952) - rzeźbiarz i medalier. Urodził się w Mielcu. Od 1911 r. z przerwami uczył w Szkole Sztuk Pięknych w Warszawie. Był członkiem Stowarzyszenia „Rzeźba” w Krakowie (1910-1914), Spółdzielni Artystów Plastyków „Ład” oraz Stowarzyszenia Artystów Polskich „Rytm” (od 1920). Tworzył kompozycje symboliczne i religijne, portrety, medale, projekty monet oraz pomniki. Rzeźby Breyera cechowała wierność naturze, silnie podkreślona statyka oraz zwar- 
sorowie Czajkowski i Jastrzębowski odnosili sukcesy na wspomnianej już Międzynarodowej Wystawie w Paryżu w 1925 r., którą poznał koad. Kajzer. Wystawa ta dała nazwę nowemu stylowi we wzornictwie przemysłowym i w sztukach plastycznych - art déco ${ }^{29}$.

Wykonane prace projektowe Jana Kajzera utorowały mu drogę do Spółdzielni Artystów Plastyków „Ład” założonej w 1926 r. przez uczniów i profesorów Akademii Sztuk Pięknych. Spółdzielni tej przez 6 lat był wiceprezesem, jeszcze jako student ASP. Zyskał uznanie środowisk artystycznych, a za projektowane prace otrzymywał nagrody pieniężne. Od pierwszego roku studiów w 1930 do 1936 r. został laureatem 5 nagród Akademii Sztuk Pięknych w postaci wyróżnień i odznaczeń za projekty wnętrz ${ }^{30}$. Również konkurs meblarski ogłoszony przez Cech Poznański w 1937 r. przyniósł mu nagrodę pieniężną w wysokości kilkuset złotych. Prace malarskie i tkaniny jego projektu wykonane przez prof. Tadeusza Pruszkowskiego i Lucjana Kintopfa oraz Helenę Bukowską zapewniły mu coroczne nagrody i były stale wystawiane w Akademii Sztuk Pięknych ${ }^{31}$.

Tymczasowe świadectwo ukończenia Akademii Sztuk Pięknych otrzymał 16 czerwca 1937 r. Złożenie pracy dyplomowej zaplanował na czas późniejszy, by najpierw ukończyć 2-letni kurs dla nauczycieli rysunków z prawem nauczania w szkołach ogólnokształcących i seminariach. Mimo że wojna przeszkodziła mu w przedstawieniu pracy dyplomowej, Ministerstwo Oświaty w 1949 r. wydało Kajzerowi dyplom nauczycielski ${ }^{32}$.

Od personelu dydaktycznego szkoły wymagał Kajzer przede wszystkim punktualności w zajęciach szkolnych, czego sam był przykładem. Potrafił dotrzeć do każdego nauczyciela. Rzucone od czasu do czasu serdeczne słowo do podwładnego świadczyło o wielkiej trosce, także o życie religijne jego i jego rodziny ${ }^{33}$. Okazywał wielkie zaufanie do nauczycieli świeckich, niekiedy większe niż do salezjanów. Podkreślano kulturę osobistą dyrektora Kajzera widoczną w jego wystąpieniach i rozmowach z nauczycielami. W relacjach służbowych dyrektornauczyciel nie doprowadzał do zatargów czy konfrontacji. Jego kwalifikacje zawodowe były bezdyskusyjne, nauczyciele szkół zawodowych cenili więc jego

tość formy. A. Melbechowska-Luty, Posagi i ludzie. Rzeźba polska dwudziestolecia międzywojennego, Warszawa 2005, s. 220.

${ }^{29}$ Art déco - styl w sztuce: architekturze, malarstwie, grafice oraz w architekturze wnętrz, rozpowszechniony w latach międzywojennych w Polsce. W architekturze wnętrz art déco łączyło tendencje funkcjonalistyczne z geometryczną stylizacją. W Polsce kierunek ten stał się głównym nurtem poszukiwań stylu narodowego i zyskał odrębność przez odwoływanie się do tradycji narodowych oraz stylu sztuki ludowej. Kostrzyńska-Miłosz, Koadiutor Jan Kajzer wspóltwórca polskiego stylu, s. 173-174; Świda, Jan Kajzer (1892-1976) wychowawca z powołania, s. 291.

${ }^{30}$ W 1935 i 1936 r. nagrody za wzory tkanin żakardowych i kilimów. W 1934 i 1935 r. za malarstwo. W 1938 r. za ceramikę. Kuzak, Wspomnienie pośmiertne, s. 2; Kostrzyńska-Miłosz, Koadiutor Jan Kajzer wspóttwórca polskiego, s. 174.

${ }^{31}$ Kuzak, Wspomnienie pośmiertne, s. 3; Świda, Jan Kajzer (1892-1976) wychowawca z powotania, s. 267.

${ }^{32}$ ASIK, sygn. A 2029, Teczka personalna koad. Jana Kajzera, Dyplom Ministerstwa Oświaty, Warszawa 24.01.1949.

${ }^{33}$ Relacja ks. Stanisława Urbańczyka, 4 sierpnia 2018, Oświęcim (zbiory własne autora). 
uwagi na temat zawodu i w ogóle stolarstwa. Nie szczędziły mu też pochwał i uznania władze Kuratorium Okręgu Szkolnego Krakowskiego ${ }^{34}$.

Jako nauczyciel posiadał rozległą i dogłębną wiedzę. Lekcje szkolne prowadził interesująco, podając także praktyczne przykłady z życia codziennego. W trakcie zajęć nigdy nie czytał, mówił bezpośrednio i zrozumiale, swoimi słowami. Pozwalał i zachęcał do rozmowy na lekcji na dany temat. Lekcje prowadził metodą dialogową, jakby poszukiwał w umysłach uczniów wiadomości i rozbudzał zainteresowanie danym tematem ${ }^{35}$. Wobec uczniów był uprzejmy, cierpliwie słuchał, doradzał, dopowiadał, zwłaszcza na warsztatach. Szczególną uwagę zwracał, by rysunki były wykonane dokładnie i solidnie. Często pocieszał zasmuconych $^{36}$.

Troszczył się o kształcenie zawodowe i pedagogiczne przyszłej kadry dydaktycznej dla szkoły. Nawet kleryków odbywających w zakładzie oświęcimskim praktykę wychowawczą obserwował, a zauważywszy zdolności i zainteresowanie zawodem stolarskim, podpowiadał księdzu inspektorowi, by kierował takiego na zaoczne studia zawodowe. To miało w przyszłości zapewnić szkole dopływ kwalifikowanej kadry dydaktycznej ${ }^{37}$.

Dzięki osobowości i cechom charakteru miał wielu przyjaciół, którzy udzielali mu pomocy, rad i nawet pewnych wskazówek dotyczących szkoły. Nauczyciele i instruktorzy niekiedy wykorzystywali jego dobroć i życzliwość, by przeprowadzić swoje prywatne plany zawodowe ${ }^{38}$.

W okresie rządów komunistycznych w Polsce Kajzer jako dyrektor prywatnej szkoły katolickiej był człowiekiem opatrznościowym. Na tym stanowisku przeżył likwidację (do 1963 r.) 20 prywatnych ponadpodstawowych szkół salezjańskich. Znaczna ich liczba posiadała uprawnienia szkół państwowych. Władze zlikwidowały funkcjonującą w zakładzie szkołę średnią ogólnokształcącą i niższe seminarium duchowne, ale szkoły zawodowej w Oświęcimiu nie odważyły się zamknąć. Mamy podstawy sądzić, że w zdecydowanej mierze była to zasługa jej dyrektora Jana Kajzera. Salezjanie pamiętający tamte czasy twierdzą, że szkoła oświęcimska w powojennym trudnym okresie „stała Kajzerem”. Jego bliscy współpracownicy nie zauważali u niego załamania, gdy zamykano szkoły średnie typu gimnazjalnego i zawodowego ${ }^{39}$.

${ }^{34}$ Świda, Jan Kajzer(1892-1976) wychowawca z powołania, s. 283.

${ }^{35}$ Tamże.

${ }^{36}$ Relacja ks. Stanisława Urbańczyka, 4 sierpnia 2018, Oświęcim (zbiory własne autora).

${ }^{37}$ Przykładem może być ks. Jakub Kręcioch. Posiadał wykształcenie średnie - technik budowlany. W czasie asystencji 1960-1962 w zakładzie oświęcimskim skierowany został przez dyrektora Kajzera na dwuletnie studia pedagogiczne do Krakowa. Dojeżdżał na zajęcia w każdy weekend i na zakończenie asystencji zdobył wykształcenie uprawniające go do prowadzenia zajęć w szkole zawodowej. Pracował w oświęcimskiej szkole w latach 1968-1974. Relacja ks. Jakuba Kręciocha, 15 czerwca 2018, Lublin (zbiory własne autora).

${ }^{38}$ AŚwida, Jan Kajzer (1892-1976) wychowawca z powołania, s. 283.

${ }^{39}$ Po II wojnie światowej w zakładzie oświęcimskim funkcjonowała kilka lat szkoła ogólnokształcąca stopnia licealnego z dołączonym później małym seminarium i szkoła zawodowa. Po likwidacji przez komunistów szkoły ogólnokształcącej i małego seminarium władze państwowe usi- 
Kajzer potrafił nawiązywać kontakty także z ludźmi wpływowymi i na stanowiskach. Dzięki absolwentom szkół salezjańskich w Polsce miał szerokie znajomości w wojewódzkich i centralnych władzach szkolnych. Okazało się to bardzo pożyteczne, gdyż lokalne władze miejskie w Oświęcimiu i miejscowi decydenci byli mało życzliwi salezjanom, chociażby z powodu konkurencji w edukacji zawodowej uczniów. Dyrektor Kajzer jeździł do Warszawy i załatwiał „sprawy trudne", np. kupno specjalnej stali do produkcji heblarko-frezarki stołowej USK. Jeśli osobiście nie mógł udać się w ważnej sprawie do władz centralnych czy wojewódzkich, wysyłał w swoim imieniu zastępcę dyrektora szkoły ks. Stanisława Urbańczyka, który właściwej osobie podawał przez sekretariat karteczkę z nazwiskiem Jana Kajzera i prośbą, a sprawa była pozytywnie załatwiona ${ }^{40}$. Od sierpnia 1971 r. ks. Urbańczyk został po Janie Kajzerze dyrektorem szkoły zawodowej i korzystał z tych znajomości głównie do załatwiania materiałów do nauki zawodu i produkcji warsztatowej w szkole.

\section{Cechy osobowości koadiutora Jana Kajzera}

Wiedziony zmysłem praktycznym i mając w pamięci robotnicze pochodzenie, Jan Kajzer wybrał stolarstwo jako kierunek kształcenia zawodowego. Zdobyte umiejętności zawodowe ukierunkowały jego życie i pracę $\mathrm{w}$ charakterze brata zakonnego, a nie kapłana, gdyż był to przyjęty w zgromadzeniu zwyczajny tryb postępowania. Najprawdopodobniej zgadzało się to z jego zamierzeniami, ponieważ nie znajdujemy jakiejkolwiek wzmianki, by zabiegał o wykształcenie teologiczne do kapłaństwa. Cenił siebie i z godnością traktował stan koadiutora salezjańskiego. Pragnął w nim osiągnąć awans naukowy i kulturalny, ale zawsze zdawał sobie sprawę, że jest to stan odmienny od stanu kapłańskiego ${ }^{41}$.

Jan Kajzer, podejmując decyzję naśladowania wielkiego wychowawcy ks. Jana Bosko, nie poprzestał na doskonaleniu metod dydaktycznych w procesie wychowania młodego człowieka, choć przede wszystkim był wychowawcą. Aby temu niełatwemu zadaniu sprostać, stawiał na pobożność i świadectwo życia, na kontakt z młodzieżą oraz na działalność artystyczną.

\section{a) Pobożność i świadectwo życia}

Nauczyciel, który swoją pracę opiera na salezjańskim systemie wychowawczym, wykorzystuje przede wszystkim nadprzyrodzone środki do ukierunkowa-

łowały wprowadzić w roku 1951/52 swojego dyrektora szkoły zawodowej. Zakończyło się na wprowadzeniu dodatkowego nauczyciela. Także wizytatorzy szkolni zgłaszali krytyczne uwagi w protokołach, podkreślali zacofanie jako skutek ,ducha wstecznictwa”, jednak z uznaniem odnosili się do osiąganych przez szkołę wyników nauczania. Stosunek władz państwowych do szkoły powoli się zmieniał, czego wyrazem było przyznanie tej prywatnej placówce praw równych państwowej zasadniczej szkole zawodowej. To dawało jej absolwentom większe możliwości otrzymania pracy w przedsiębiorstwach państwowych. Świda, Jan Kajzer (1892-1976) wychowawca z powołania, s. 274; Żurek, Salezjańskie szkolnictwo ponadpodstawowe w Polsce, s. 424; Kuzak, Wspomnienie pośmiertne, s. 8.

${ }^{40}$ Relacja ks. Stanisława Urbańczyka, 4 sierpnia 2018, Oświęcim (zbiory własne autora).

${ }^{41}$ Świda, Jan Kajzer (1892-1976) wychowawca z powołania, s. 263-264. 
nia procesu wychowania. Taki tryb postępowania wymaga od wychowawcy pewnej postawy - świętości życia, a ta ujawnia się m.in. w pobożności, która wpływa na skuteczność oddziaływania i jest formą świadectwa dla młodzieży.

Świadkowie życia koad. Kajzera podkreślają jego osobistą pobożność i wierność salezjańskim praktykom pobożnym, określając go jako człowieka głębokiej wiary, żyjącego w skupieniu i zjednoczeniu z Bogiem. Wśród namiętnego oddania się pracy nie zaniedbywał nigdy pobożnych praktyk zakonnych: rozmyślania, uczestnictwa we mszy św., czytania duchownego, nawiedzenia Najświętszego Sakramentu tak wspólnotowego, jak i prywatnego, tygodniowej spowiedzi i dorocznych rekolekcji. Codziennie uczestniczył we mszy św. wspólnie w wychowankami. Niektórzy salezjanie (ks. Leon Musielak) twierdzili, że był człowiekiem wyjątkowo rozmodlonym ${ }^{42}$.

Spośród nabożeństw, jakie praktykował, największą uwagę skupiał na nabożeństwie maryjnym. Kult Maryi Wspomożycielki Wiernych uformował w nim świadomość, że Maryja ustawicznie opiekuje się nim samym i szkołą zawodową, której był dyrektorem ${ }^{43}$. Poruszające się wargi, oczy utkwione w obraz Wspomożycielki lub w ołtarz, na którym składana była Najświętsza Ofiara - świadczyły o jego złączeniu z Bogiem i Wspomożycielką, do której w trudniejszych sytuacjach życiowych zwracał się o pomoc. Współpracujący z Janem Kajzerem przez 25 lat koad. Edmund Moś tak go wspomina: „Nigdy nie zauważyłem u niego jakiegoś załamania. Często mi mówił: Edmund módl się, bo jest źle, ale to wszystko w rękach Opatrzności, Maryi Wspomożycielki i Świętego Józefa. Róbmy, co możemy, a resztę zostawmy Wspomożycielce i św. Janowi Bosko"44. Wezwanie „Maryjo Wspomożenie Wiernych, módl się za nami” wypowiadał zawsze, gdy przechodził obok obrazów maryjnych. Nie rozstawał się z różańcem, na którym modlił się w kościele, w pokoju, w podróży, przy pracy. Gdy się modlił w kaplicy św. Jacka czy w kościele, odmawiał szeptem „Ojcze nasz”, „Zdrowaś Maryjo” po wielekroć razy z głębokim namaszczeniem ${ }^{45}$.

Nabożeństwo do Matki Bożej pragnął Jan Kajzer wszczepić innym, głównie wychowankom i uczniom oświęcimskim. Dlatego w rozmowach z młodymi ukazywał cnoty Matki Najświętszej: czystość, posłuszeństwo i miłość, zachęcając do praktykowania ich w życiu. Będąc już na emeryturze, spędzał czas na korytarzu zakładowym, aby nadal mieć kontakt z wychowankami. Nierzadko obdarowywał ich medalikami i obrazkami religijnymi ${ }^{46}$.

Jan Kajzer wprowadził praktykę codziennego apelu porannego uczniów i nauczycieli, którzy gromadzili się przed lekcjami na głos dzwonka na obszernym

${ }^{42}$ Kuzak, Wspomnienie pośmiertne, s. 9; Świda, Jan Kajzer (1892-1976) wychowawca z powotania, s. 278.

${ }^{43} \mathrm{~W}$ historii salezjanów w Polsce jego dyrektorstwo w szkole było doniosłe, ustalonym bowiem zwyczajem dyrektorem szkoły reprezentującym ją wobec władz państwowych był kapłan i dyrektor domu/zakładu salezjańskiego. Świda, Jan Kajzer (1892-1976) wychowawca z powołania, s. 272.

${ }^{44}$ Tamże, s. 283.

${ }^{45}$ ASIK, sygn. 2029, Teczka personalna koad. Jana Kajzera, S. Ślebioda, Działalność dydaktyczna i pedagogiczna Jana Kajzera, Oświęcim 10 grudnia 1983, s. 3.

${ }^{46}$ Świda, Jan Kajzer (1892-1976) wychowawca z powolania, s. 287. 
korytarzu na parterze zakładu (mogło się tam zebrać nawet ponad 1000 osób). Na początku odmawiano wspólnie modlitwy poranne, po których dyrektor Kajzer podawał bieżące i ważne informacje dla uczniów i nauczycieli, ogłaszał rozporządzenia władz szkolnych oraz ciekawsze nowiny z kraju i świata. Na apelu porannym zabierali głos także nauczyciele lub przedstawiciele dyrekcji zakładu. Jednak zdecydowana większość wystąpień apelowych należała do dyrektora szkoły ${ }^{47}$. Wielu zauważało, choć nie wszyscy to rozumieli, że dyrektor przed zabraniem głosu na apelu porannym zatrzymywał się przez chwilę przed figurą św. Józefa usytuowaną przy wejściu na korytarz zakładowy, po czym rozpoczynał przemówienie $^{48}$. Jeden z jego bliskich współpracowników napisał: „Kajzer zawsze przed każdą figurą czy obrazem poświęconym zatrzymywał się... i domyślam się, że tym aktem łączył się z Bogiem" "^9 . Przechodząc obok figury św. Józefa, zawsze skłonił głowę i szeptał modlitwę ${ }^{50}$.

Inną formą pobożności Kajzera było nawiedzanie Najświętszego Sakramentu w kościele Maryi Wspomożycielki Wiernych i w kaplicy św. Jacka na wewnętrznym podwórku zakładowym. Odprawiał tę praktykę pobożną wspólnie z salezjanami, ale także prywatnie. Podczas takiej „modlitwy osobistej” nie czuł się skrępowany określoną postawą zewnętrzną. Jego współbrat Henryk Kuglin wspomina: „Często spędzał swój wolny czas na samotnej rozmowie z Jezusem Eucharystycznym w oświęcimskim kościele. Wtedy gdy czuł, że jest sam, uczucia religijne wyrażał gestami lub modlił się głośno"s1.

Dyrektor Jan Kajzer uczestniczył w zjazdach dyrektorów szkół i w okresowych konferencjach pedagogicznych nauczycieli, w ramach których odbywały się poczęstunki. Większość uczestników takich spotkań, głównie dyrektorzy szkół, była członkami Polskiej Zjednoczonej Partii Robotniczej. W takim gronie przed posiłkiem Kajzer czynił znak krzyża świętego, żegnając się ,zamaszyście”. Podobnie czynił na zakończenie posiłku. Nie zdarzyło się, by z tego powodu spotkał się z uwagą krytyczną ${ }^{52}$.

Pobożność Jana Kajzera uwidaczniała się w jego życiu zawodowym i prywatnym, w odnoszeniu się do współpracowników i podwładnych oraz do uczniów i wychowanków. Doceniał wartość przeczytanej książki religijnej, a budujące przykłady z życia świętych przekazywał na co dzień wychowankom ${ }^{53}$.

\footnotetext{
${ }^{47}$ Relacja ks. Stanisława Urbańczyka, 4 sierpnia 2018, Oświęcim (zbiory własne autora).

${ }^{48} \mathrm{~W}$ świadomości salezjanów organizujących i budujących zakład oświęcimski tkwiło uzasadnione przekonanie, iż wstawiennictwo św. Józefa uratowało zakład z powodu skutków chybionej loterii fantowej. Budowniczy zakładu - ks. Emanuel Manassero wypełniając przyrzeczony ślub, polecił umieścić statuę św. Józefa w głównym korytarzu zakładu jako wotum wdzięczności salezjanów i wychowanków dla św. Józefa, do którego nabożeństwo jest pielęgnowane. J. Ptaszkowski, Rzecz o dobrej sławie Oświęcimia. Karty z historii Zakładu Księdza Bosko, Kraków 1998, s. 96.

${ }^{49}$ Kuzak, Wspomnienie pośmiertne, s. 9.

${ }^{50}$ Ptaszkowski, Rzecz o dobrej sławie Oświęcimia, s. 96; Świda, Jan Kajzer (1892-1976) wychowawca z powolania, s. 283.

${ }^{51}$ Cyt. za: Kowol, Działalność dydaktyczna i pedagogiczna Jana Kajzera, s. 61.

${ }^{52}$ Relacja ks. Stanisława Urbańczyka, 4 sierpnia 2018, Oświęcim (zbiory własne autora).

${ }^{53}$ A. Świda, Jan Kajzer (1892-1976) wychowawca z powołania, s. 283.
} 


\section{b) Kontakt z młodzieżą - salezjańska „asystencja”}

Zawodowe przygotowanie uczniów leżało dyrektorowi Kajzerowi na sercu, ale przejęty był również ich wychowaniem religijno-moralnym. Tego typu wychowanie wymagało od wychowawcy ogromnego poświęcenia. Przez całe życie i w każdym miejscu był salezjaninem asystentem przebywającym wśród wychowanków: w kościele, na przerwach międzylekcyjnych i na rekreacji. Rozmawiał $\mathrm{z}$ uczniami w grupie, a w razie potrzeby na osobności. Szukał możliwości pomocy młodemu człowiekowi. Badawczo patrzył w oczy rozmówcy, stąd powstało w tamtym czasie powiedzenie: „byłeś na oczku”. Takim rozmowom poświęcał wiele czasu i co ciekawe - umiał poruszanymi tematami zainteresować młodych uczniów. Przy tej okazji opowiadał wychowankom wiele interesujących epizodów z żywotów świętych. Dla młodzieży nie zawahał się zrezygnować z wykładów w Akademii Sztuk Pięknych w Warszawie ${ }^{54}$.

Jan Kajzer do celów wychowawczych używał też metod niekonwencjonalnych, a do takich należało tzw. słówko na ucho, wypowiedziane mimochodem, by ustrzec wychowanka przed nierozważnym krokiem. Te krótkie rady, podpowiedzi czy upomnienia przynosiły pożądane skutki. Pomagały wychowankom dostrzec i zmienić niewłaściwe zachowania i wziąć odpowiedzialność za swoje czyny. Taką metodę Jan Kajzer stosował już jako asystent w szkole oświęcimskiej, gdzie w latach 1915-1917 pomagał w pracowni stolarskiej, a od 15 października $1915 \mathrm{r}$. nią kierowa ${ }^{55}$.

Jako dyrektor szkoły niejednokrotnie zmuszony był reagować na niewłaściwe zachowanie uczniów. Niezdyscyplinowanych nie poniżał, lecz po ojcowsku thumaczył, zachęcał do zmiany postępowania, do stawiania sobie pewnych wymagań, do czynienia postanowień w pracy nad sobą ${ }^{56}$. Uczniów zagrożonych wydaleniem ze szkoły starał się ratować, dawał im szansę na poprawę, nikogo nie przekreślając. Jednak gdy większość nauczycieli domagała się wydalenia ucznia ze szkoły, dyrektor Kajzer ze smutkiem i żalem przychylał się do ich zdania, a na siebie brał ciężar rozmów z uczniem opuszczającym szkołę lub z jego rodzicami ${ }^{57}$.

Trzeba pamiętać, że pewna liczba uczniów oświęcimskiej szkoły przechodziła przez domy poprawcze, a salezjański zakład ze szkołą zawodową wydawał się dla ich rodziców ostatnią deską ratunku dla zwichniętych moralnie synów. Ci chłopcy potrzebowali od personelu dydaktycznego i wychowawczego szczególniejszej troski. Tak uważał Jan Kajzer, dlatego jako salezjanin i dyrektor szkoły czuł się szczególnie odpowiedzialny za szkołę i wychowanie uczniów. Był pewny, że właściwych owoców wychowania można się spodziewać, stosując w procesie wychowawczym system prewencyjny zalecany przez księdza Jana Bosko ${ }^{58}$. Stąd praktyki religijne i asystencję uważał za pierwszorzędne środki w wychowaniu.

${ }^{54}$ Tamże, s. 268.

${ }^{55}$ Kowol, Działalność dydaktyczna i pedagogiczna Jana Kajzera, s. 68; Żurek, Szkoły salezjańskie w Oświęcimiu, s. 489, 516.

${ }^{56}$ Kowol, Działalność dydaktyczna i pedagogiczna Jana Kajzera, s. 69.

${ }^{57}$ Tamże.

${ }^{58}$ Kuzak, Wspomnienie pośmiertne, s. 7-8; relacja ks. Stanisława Urbańczyka, 4 sierpnia 2018, Oświęcim (zbiory własne autora). 
Jako dyrektor zabiegał, aby inspektor salezjański na rozpoczęcie roku szkolnego przemówił do personelu nauczycielskiego i wychowawczego, wyjaśniając, że salezjański system wychowawczy jest systemem uprzedzającym. Absolwent oświęcimskiej szkoły napisał po latach do dyrektora Jana Kajzera: „Proszę nie myśleć, że zapomniałem o zakładzie, przeciwnie, stale wspominam miłe chwile spędzone w nim (...) dostałem w tym zakładzie najlepsze wychowanie. Jestem bezgranicznie wdzięczny za to, co tutaj otrzymałem (...) dostałem wychowanie w duchu katolickim i moralnym. Nigdy wam tego nie zapomnę, Księża Salezjanie" 59 .

Dyrektor Jan Kajzer hospitował naukę praktyczną na wszystkich działach zawodowych oraz zajęcia lekcyjne. W ten sposób nie tylko wypełniał swój zawodowy obowiązek, ale pragnął poznawać uczniów i ich problemy związane nie tylko z edukacją zawodową. Po apelu porannym, gdy uczniowie udawali się do sal lekcyjnych i do pracowni zawodowych, Kajzer obchodził poszczególne działy kształcenia zawodowego w salach lekcyjnych i w pracowniach. Przyglądał się, jak uczniowie angażują się w naukę zawodu, i starał się podpatrywać usterki organizacyjne. W razie potrzeby rozmawiał „na ucho” z uczniem czy instruktorem zawodu $^{60}$. Nawet gdy przeszedł na emeryturę, interesował się nauką uczniów, podpatrywał i doradzał. Nie porzucił też codziennej praktyki asystencji, czyli przebywania wśród uczniów i wychowanków zakładu, a jego uśmiech i pogoda ducha ujmowały młodzież ${ }^{61}$.

\section{c) Działalność artystyczna Jana Kajzera}

Jan Kajzer uważał, że należy żyć tak, aby czynić dobro. Pracując w czasie II wojny światowej poza zgromadzeniem w Hołubli, pisał: „Wprawdzie jest mi dobrze, ale myślę żyć nie jedynie dla mej wygody, tylko po to, aby co dobrego wykonać w życiu" ${ }^{\prime 2}$.

Dowodem jego pracowitości są m.in. wykonane przez niego szkice i projekty architektoniczne. Szkoda, że po zrealizowaniu projektu nie dbał o jego zabezpieczenie i przechowanie, gdyż wiele z nich się nie zachowało. Mimo słabego wzroku wykonywał wspaniałe projekty stolarskie mebli, ołtarzy, konfesjonałów, chrzcielnic, balasek kościelnych oraz wyposażenia wnętrza świątyni. Ksiądz Urbańczyk wspominał: „Wyobrażamy sobie, ile czasu i trudu wymagało od niego sporządzenie projektu, np. wystroju kościoła czy ołtarza głównego? Jak sam wyznał - około roku. A jak wykonywał swoje projekty? Rozpoczynał od sporządzenia rysunku obiektu. Następnie, sporządzając projekt, zmuszony był śledzić swoje prace z odległości kilkunastu centymetrów. Noszone przez niego coraz silniejsze okulary niewiele oddalały go od sztalugi i oczy w czasie pracy miał tuż przy samym pulpicie, na którym leżał projekt. I chociaż wydawałoby się, że z bliska nie

${ }^{59}$ Cyt. za: Kuzak, Wspomnienie pośmiertne ..., s. 8.

${ }^{60}$ ASIK, sygn. A 2029, Teczka personalna koad. Jana Kajzera, S. Ślebioda, Działalność dydaktyczna i pedagogiczna Jana Kajzera, Oświęcim 10 grudnia 1983, s. 2.

${ }^{61}$ Kuzak, Wspomnienie pośmiertne..., s. 9; Świda, Jan Kajzer (1892-1976) wychowawca z powotania, s. 283 .

${ }^{62}$ ASIK, sygn. A 2029, Teczka personalna koad. Jana Kajzera, Jan Kajzer do inspektora ks. Jana Ślósarczyka, 24 czerwca 1943, Hołubla. 
miał możliwości widzenia $\mathrm{w}$ perspektywie, to on $\mathrm{w}$ głowie wszystko widział z perspektywy"63.

Mnóstwo szkiców, kreślonych i poprawianych, nosił w kieszeni marynarki. W chwilach wolnych sięgał po nie i myślał nad dalszą realizacją projektu. To świadczyło o skupieniu jego myśli, którą ożywiał drzewo, żelazo, marmur, złoto ${ }^{64}$.

Koadiutor Jan Kajzer był człowiekiem rozmiłowanym w swoim zawodzie stolarskim. Mimo że był obarczony ogromną pracą i wielką odpowiedzialnością $\mathrm{z}$ racji zajmowanego stanowiska dyrektora szkoły i nauczyciela, nie odstępował od sztalugi. Przez całe życie, także będąc już na emeryturze, wykonywał na niej kolejne prace. Projektował i nadzorował wykonanie prac stolarskich (ołtarzy, konfesjonałów, figur świętych) nie tylko dla zakładu oświęcimskiego i kościołów salezjańskich w Polsce.

\section{Dzialalność usługowa Jana Kajzera}

Na początku stycznia 1917 roku r. kierownictwo zakładu oświęcimskiego i szkoły rzemieślniczej uzyskało u władz centralnych w Krakowie (Centrala Krajowa dla Gospodarczej Odbudowy Galicji - Sekcja III) subwencję na zmodernizowanie pracowni zawodowych w Oświęcimiu, które świadczyły usługi ślusarskie, stolarskie i kowalskie miejscowym i okolicznym rolnikom. Najbardziej potrzebne były dobre lemiesze do pługów konnych dla okolicznych rolników. Po 1945 r. dyrektor szkoły zawodowej tę tradycję podtrzymywał i usługi były świadczone bez ograniczeń dla wszystkich zgłaszających się do poszczególnych pracowni zawodowych.

Oświęcimska szkolna pracownia stolarska wykonała wyposażenie szkolnych gabinetów naukowych dla własnej szkoły. Dyrektorzy i grono nauczycielskie szkół odbywający zjazdy i okresowe konferencje w zakładzie oświęcimskim podobne wyposażenie zamawiali dla swoich placówek. Oświęcimska szkoła zaopatrzyła placówki dydaktyczne w powiecie i w województwie w umeblowanie wykonane zgodnie z obowiązującymi przepisami szkolnymi, sanitarnymi i zasadami bezpieczeństwa ${ }^{65}$.

Wspomina ks. Urbańczyk: „Znany panu Kajzerowi rzemieślnik z Warszawy produkował guziki. Gdy jego maszyna uległa awarii i produkcja stanęła, wówczas ks. Stanisław Urbańczyk z nauczycielem zawodu Tadeuszem Jaroszem zostali wysłani przez pana Kajzera z pomocą, celem usunięcia awarii. Wzięli ze sobą własnej produkcji obrabiarkę skrawającą USK-ę, za pomocą której planowali usunąć usterkę (...) wykonali na miejscu nowy wałek-stożek, mając do dyspozycji przywiezioną obrabiarkę. Taki tok myślenia i podejścia do załatwienia petentów prezentował koad. Jan Kajzer. Tym sposobem zareklamowali przy okazji własny wyrób - obrabiarkę skrawającą" ${ }^{96}$.

\footnotetext{
${ }^{63}$ Relacja ks. Stanisława Urbańczyka, 4 sierpnia 2018, Oświęcim (zbiory własne autora).

${ }^{64}$ Tamże.

${ }^{65}$ Tamże.

${ }^{66}$ Tamże.
} 
Tabela 1. Wybrane projekty Jana Kajzera i ich realizacja przez stolarską pracownię szkolną 1914-1964

\begin{tabular}{|c|c|c|c|}
\hline Lp. & Miejscowość & Rok & Rodzaj projektu \\
\hline 1 & 2 & 3 & 4 \\
\hline 1 & Oświęcim - apteka & przed 1914 & $\begin{array}{l}\text { Projekt i wykonanie wyposażenia do ap- } \\
\text { teki miejskiej }\end{array}$ \\
\hline 2 & USA & & Wykonanie trzech konfesjonałów \\
\hline 3 & Przemyśl - Zasanie & XI 1927 & $\begin{array}{l}\text { Projekt i wykonanie ołtarza głównego do } \\
\text { kościoła św. Józefa }\end{array}$ \\
\hline 4 & $\begin{array}{l}\text { Lutowiska, } \\
\text { diec. przemyska }\end{array}$ & 1933 & Projekt i wykonanie ołtarza gotyckiego \\
\hline 5 & Balice, pow. Busko & 1940 & Projekt ołtarza i kierowanie jego budową \\
\hline 6 & Hołubla, pow. Siedlce & $1942 / 43$ & $\begin{array}{l}\text { Projekt ołtarza, ambony, balustrady, po- } \\
\text { sadzki i polichromii. Nadzór nad wykona- } \\
\text { niem tych prac }\end{array}$ \\
\hline 7 & Sokołów Podlaski & 1943 & $\begin{array}{l}\text { Projekt do salezjańskiego kościoła pw. św. } \\
\text { Jana Bosko }\end{array}$ \\
\hline 8 & Sokołów Podlaski & 1943 & $\begin{array}{l}\text { Dwukrotnie wykonane modele ołtarza } \\
\text { z figurą Matki Bożej do kościoła parafial- } \\
\text { nego }\end{array}$ \\
\hline 9 & - & 1943 & $\begin{array}{l}\text { Wykonanie ołtarza bocznego u probosz- } \\
\text { cza ks. Fondalińskiego }\end{array}$ \\
\hline 10 & Łuków & X 1943 & Projekt polichromii kościoła \\
\hline 11 & $\begin{array}{l}\text { Lublin, } \\
\text { ul. Kalinowszczyzna } 3\end{array}$ & V 1949 & $\begin{array}{l}\text { Projekt i wykonanie ołtarza głównego } \\
\text { w miedzi z obrazem Maryi Wspomoży- } \\
\text { cielki }\end{array}$ \\
\hline 12 & Żywiec Zabłocie & VIII 1952 & Projekt szkiców do ołtarza bocznego \\
\hline 13 & Szczyrk & 1953 & $\begin{array}{l}\text { Projekt ołtarza do kościoła salezjańskiego } \\
\text { „na Górc”e }\end{array}$ \\
\hline 14 & Łódź & IX 1956 & $\begin{array}{l}\text { Ołtarz boczny 12-metrowy i drzwi ozdob- } \\
\text { ne do parafii MB Częstochowskiej }\end{array}$ \\
\hline 15 & Sokołów Podlaski & 1956 & $\begin{array}{l}\text { Dwukrotnie wykonane modele ołtarza z fi- } \\
\text { gurą Matki Boskiej w parafii diecezjalnej }\end{array}$ \\
\hline 16 & Garbów k. Lublina & 1957 & $\begin{array}{l}\text { Projekt chrzcielnicy 10-metrowej z figurą } \\
\text { św. Jana Chrzciciela }\end{array}$ \\
\hline
\end{tabular}




\begin{tabular}{|c|c|c|c|}
\hline 1 & 2 & 3 & 4 \\
\hline 17 & Poznań & 1958 & $\begin{array}{l}\text { Klęcznik dla abpa Antoniego Baraniaka } \\
\text { w darze z okazji jego ingresu do katedry } \\
\text { poznańskieja }\end{array}$ \\
\hline 18 & Czeladź & 1959 & Projekt ołtarza głównego \\
\hline 19 & Łódź & VII 1963 & $\begin{array}{l}\text { Projekt tabernakulum do parafii św. Stani- } \\
\text { sława Kostki }\end{array}$ \\
\hline 20 & Oświęcim & 1963 & $\begin{array}{l}\text { Projekt i wykonanie ołtarza do kościoła } \\
\text { MB Wspomożenia Wiernych i ławek ko- } \\
\text { ścielnych }\end{array}$ \\
\hline 21 & Oświęcim & - & $\begin{array}{l}\text { Wykonanie pod nadzorem Kajzera dużego } \\
\text { konfesjonału i sześciu mniejszych, w stylu } \\
\text { gotyckim }\end{array}$ \\
\hline 22 & Poznań & 31 I 1964 & $\begin{array}{l}\text { Ołtarz do kaplicy abpa Baraniaka wyko-- } \\
\text { nany przez uczniów szkoły oświęcimskiej } \\
\text { pod kierunkiem Jana Kazjera i Edmunda } \\
\text { Mosia }\end{array}$ \\
\hline 23 & Mysłowice & - & $\begin{array}{l}\text { Projekt i wykonanie chrzcielnicy z drzewa } \\
\text { dębowego w stolarni zakładowej w Oświę- } \\
\text { cimiu }\end{array}$ \\
\hline 24 & Kraków, ul. Tyniecka 39 & - & $\begin{array}{l}\text { Projekt posadzki kamionkowej w kaplicy } \\
\text { MB Wspomożenia Wiernych }\end{array}$ \\
\hline 25 & Zamość, ul. Powstańców & - & $\begin{array}{l}\text { Projekt konfesjonału, drzwi ozdobnych do } \\
\text { ogrodzenia kościoła, wykonane pod nad- } \\
\text { zorem Kajzera w pracowni oświęcimskiej }\end{array}$ \\
\hline 26 & Bieruń Stary & - & Ołtarz do kościoła parafialnego \\
\hline
\end{tabular}

Patrząc na powyższą tabelę niektórych projektów i ich wykonania pod kierunkiem Jana Kajzera, odnosi się wrażenie, że tak realizował hasło ora et labora. Praca wypełniała mu czas, nie tracił go i uczył innych go szanować. „Możesz mi koperty do siebie drukować ze znaczkiem pocztowym, to mi ulżysz w czasie”, tak

a Po otrzymaniu klęcznika abp Baraniak napisał do Jana Kajzera: „Klęcznik ten zdobić będzie moją kaplicę prywatną w pałacu Arcybiskupim. Codziennie odmawiam na klęczniku tym swoje modlitwy kapłańskie i mszalne. Pamiętam też w modlitwach swoich o tych, którzy go wykonali. Cieszę się ogromnie, że to 'mój klęcznik', dar Współbraci mojej umiłowanej Rodziny Salezjańskiej”. Archiwum Archidiecezjalne w Poznaniu, sygn. OA XIII 499, Abp A. Baraniak do ko. Jana Kajzera, Poznań 13 stycznia 1958. 
pisał do ks. Leona Czerwińskiego, dyrektora domu zakonnego i szkoły średniej w Ostrzeszowie, który zasypywał go swoimi listami ${ }^{67}$.

Dyrekcja szkoły przyjmowała zamówienie na wszelkie usługi warsztatów szkolnych na rzecz internatu zakładowego czy w ogóle zakładu salezjańskiego. Szkoła rzemieślnicza i internat dla uczniów mieściły się w obszernym budynku zakładu, stąd niejednokrotnie trudno było rozgraniczyć, co stanowiło usługę wyłącznie dla zakładu, a co dla szkolnego internatu.

W uznaniu zasług za 26 lat dyrektorstwa w salezjańskiej szkole zawodowej w Oświęcimiu Jan Kajzer otrzymał odznaczenie papieskie „Pro Ecclesia et Pontifice" ${ }^{68}$, a w dowód wdzięczności za pracę zawodową związaną z wychowaniem i nauczaniem młodzieży wręczono dyrektorowi w 1971 r. od Samorządu Zasadniczej Szkoły Zawodowej w Oświęcimiu album ze zdjęciami obrazującymi lata jego pracy.

Obok takich członków zgromadzenia salezjańskiego jak kard. August Hlond prymas Polski, abp Antoni Baraniak - metropolita poznański, brat koadiutor Klemens Hlond - uczestnik powstań śląskich, wybitny wychowawca i nauczyciel na misjach, brat koadiutor Szymon Szmergalski - męczennik II wojny światowej, cieszący się opinią świętości, jest miejsce dla wielu innych, którzy zasługują na trwałą pamięć. Do takich należy salezjański brat zakonny koadiutor inż. Jan Kajzer.

\section{Zakończenie}

Rok szkolny 1947/48 był rokiem największego rozwoju działalności oświatowej salezjanów po II wojnie światowej. W latach późniejszych na skutek polityki władz komunistycznych liczba ich placówek stopniowo się zmniejszała. Nawet zastępowanie gimnazjów niższymi seminariami duchownymi nie uratowało ich od upaństwowienia, czyli likwidacji. W procesie likwidacji prywatnego sektora szkół władze komunistyczne zachowywały pozory prawa. Szkołom tym narzucano własny personel dydaktyczny, zarzucając dotychczasowemu niekompetencję, usiłowano wprowadzać organizacje szkolne (Związek Młodzieży Polskiej, ZHP ściśle współpracujący z rządzoną w Polsce PZPR) przeciwne charakterowi szkół

${ }^{67}$ ASIK, sygn. A 2029, Teczka personalna koad. Jana Kajzera; Z. Kuzak. Wspomnienie pośmiertne, s. 5; A. Świda, Jan Kajzer (1892-1976) wychowawca z powołania, s. 266.

${ }^{68}$ Pro Ecclesia et Ponitifice, Za Zasługi dla Kościoła i Pontyfikatu - medal papieski jako odznaczenie honorowe ustanowione zostało w $1887 \mathrm{r}$. i przyznawane osobom świeckim o nienagannej postawie moralnej, zaangażowanym w życie Kościoła i chrześcijańskiej kultury. Odznaczenie to ustanowił papież Leon XIII dla osób szczególnie zaangażowanych w organizację jego złotego jubileuszu kapłaństwa i 10-lecia pontyfikatu. Zawierało ono wizerunek papieża i inskrypcję: LOE XIII P.M.ANN.X. Medal ukazał się w trzech wersjach: złotej, srebrnej i brązowej. W 1908 r. papież Pius X zmodyfikował formę medalu, likwidując egzemplarze złote. Natomiast papież Paweł VI zamiast wizerunku papieża polecił umieścić podobizny apostołów Piotra z kluczami w ręku i Pawła z Ewangelią i mieczem oraz wykonać je w mosiądzu i aluminium. W dolnej części krzyża orderowego umieszcza się łacińskie imię aktualnego papieża. Medal początkowo miał charakter pamiątkowy. Obecnie należy do orderów papieskich i przyznawany jest przez papieża na wniosek ordynariusza diecezji. J.B. Stachowiak, Pro Ecclesia et Pontifice, Za Zastugi dla Kościoła i Pontyfikatu, w: Encyklopedia katolicka, t. 16, red. E. Gigilewicz, Lublin 2012, kol. 409. 
katolickich, wykazywano nielojalność personelu wobec władz oświatowych i zacofanie w pracy wychowawczej. W latach 1949-1963 upaństwowiono w Polsce Ludowej 20 prywatnych szkół salezjańskich. W samym Oświęcimiu trzy: Małe Seminarium, Gimnazjum Ogólnokształcące i Szkołę Rzemiosł Budowlanych w Oświęcimiu-Zasolu. Pozostała tylko jedna salezjańska szkoła zawodowa w Zakładzie im. Księdza Bosko w Oświęcimiu, której dyrektorem był pan Jan Kajzer. Władza komunistyczna padła, a szkoła ta funkcjonuje nieprzerwanie do dziś.

\section{Źródła}

\section{REFERENCES / BIBLIOGRAFIA}

Archiwum Salezjańskiej Inspektorii Krakowskiej - ASIK

sygn. A 2029, Teczka personalna koad. Jana Kajzera: Życiorys Jana Kajzera (Oświęcim 20 stycznia 1951); Kajzer Jan, Moje przeżycia od 1 IX 1939 roku [mps].

Zespół: Listy pośmiertne współbraci, T. III: $\mathrm{K}$ - Ł:

Kuzak Zygmunt, Wspomnienie pośmiertne o śp. koad. Janie Kajzerze [mps].

Ślebioda Stanisław, Działalność dydaktyczna i pedagogiczna Jana Kajzera, Oświęcim 10 grudnia 1983, [mps].

\section{Relacje}

Relacja ks. Jakuba Kręciocha, 15 czerwca 2018, Lublin (zbiory własne autora).

Relacja ks. Stanisława Urbańczyka, 4 sierpnia 2018, Oświęcim (zbiory własne autora).

\section{Opracowania}

Braido Pietro, Prevenire non reprimere. Il sistema educativo di don Bosco, Roma 1999. Janneau Guillaume, Encyklopedia sztuki dekoracyjnej, Warszawa 1978.

Jastrzębowski Wojciech, w: Nowa encyklopedia powszechna PWN, tom 3: I- - , Warszawa 1995, s. 154.

Kintopf Lucjan, w: Nowa encyklopedia powszechna PWN, tom 3: I-, , Warszawa 1995, s. 356.

Kostrzyńska-Miłosz Anna, Koadiutor Jan Kajzer wspóttwórca polskiego stylu art deco, „Seminare”, 35 (2014) nr 1, s. 171-179.

Kowol Paweł, Działalność dydaktyczna i pedagogiczna Jana Kajzera (1892-1976), Lublin 1989 [mps KUL].

Melbechowska-Luty Aleksandra, Posagi i ludzie. Rzeźba polska dwudziestolecia międzywojennego, Warszawa 2005.

Niewęgłowski Jan SDB, Wychowawczo-spoleczna działalność salezjanów w Polsce w latach 1898-1989, Warszawa 2011.

Personel salezjański $i$ wychowankowie Zakładu im. Księdza Bosko w Oświęcimiu 18981917, oprac. i wyd. Waldemar Witold Żurek SDB, Lublin 2014. 
Pietrzykowski Jan, Towarzystwo Salezjańskie w Polsce w warunkach okupacji 1939-1945, Warszawa 2015.

Ptaszkowski Jan, Rzecz o dobrej stawie Oświęcimia. Karty z historii Zakładu Księdza Bosko, Kraków 1998.

Salezjańskie szkoły rzemieślnicze w Oświęcimiu 1914-1971. Kronika, oprac. i wyd. W.W. Żurek SDB, Lublin 2018.

Stachowiak Jan Bogumił, Pro Ecclesia et Pontifice, Za Zastugi dla Kościoła i Pontyfikatu, w: Encyklopedia katolicka, t. 16, Lublin 2012, kol. 409.

Świda Andrzej SDB, Jan Kajzer (1892-1976) wychowawca z powołania, w: Chrześcijanie, t. 12, red. Bohdan Bejze, Warszawa 1984, s. 260-292.

Świda Andrzej, Salezjańskie szkolnictwo w Polsce (zarys), w: 75 lat działalności salezjanów w Polsce, red. Remigiusz Popowski, Stanisław Wilk, Marian Lewko, Łódź-Kraków 1974, s. 37-59.

Tichy Karol Józef, w: Wielka encyklopedia powszechna PWN, tom 11, Warszawa 1968, S. 524.

Żurek Waldemar SDB, Salezjańskie szkolnictwo ponadpodstawowe w Polsce 1900-1963. Rozwój i organizacja, Lublin 1996.

Żurek Waldemar Witold, Szkoty salezjańskie w Oświęcimiu na tle salezjańskiego szkolnictwa średniego ogólnokształcącego i zawodowego na ziemiach polskich, Lublin 2010.

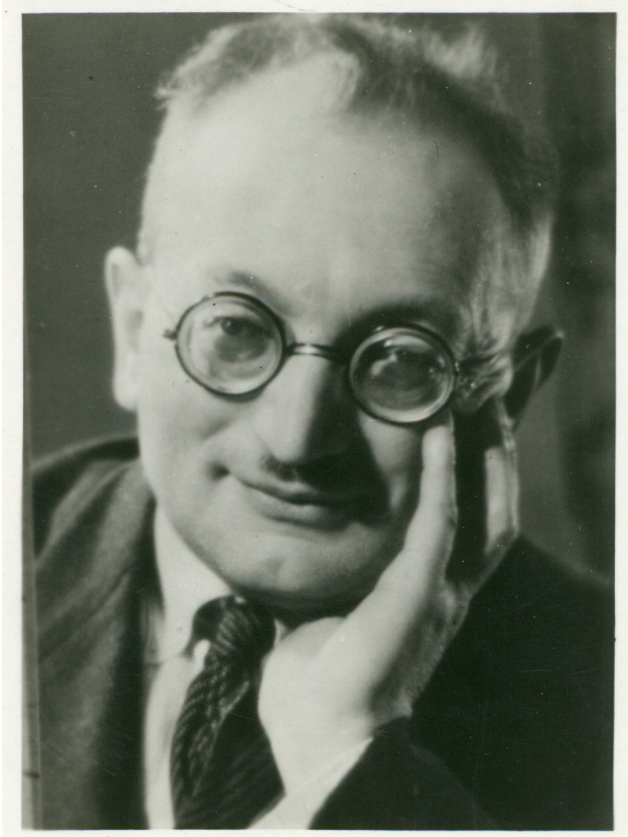

Il. 1. Koadiutor Jan Kajzer Zbiory ASIK, Kraków 
A SALESIAN FATHER, TUTOR, ARTIST - LIFE AND ACTIVITY. COADIUTOR JAN KAJZER (1892-1976)

\begin{abstract}
This article presents the figure of Jan Kajzer (1892-1976), a Salesian, tutor and author of many projects about usable art. A long time teacher and director of the technical school in the Salesian Father Bosko Institute in Oświęcim, he defended this school against the communist influence, and fulfilled his duties with devotion. Behind, he was author of many furniture projects, particularly for church use, tissues and paintings, which gained approval in the art milieu. Privately he was know as a deeply religious man, following the sample of St. Bosko. In this article, Jan Kajser is presented as one of the most eminent members of the Salesian Congregation of Poland, like August Hlond, Archbishop Antoni Baraniak, Bishop Adam Śmigielski.
\end{abstract}

Keywords: Jan Kajzer; the history of the Salesian Congregation; the Salesian Fr. Bosko Institute in Oświęcem; Salesian education 